\title{
Diabetes Mellitus Type 1, Latent Autoimmune Diabetes of Adults and Hepatitis C Virus: What we Know and what we Need to Know
}

\author{
Grazia Tosone*, Alberto Enrico Maraolo, Giulia Palmiero, Silvia Mascolo and Raffaele Orlando
}

Department of Clinical Medicine and Surgery - Section of Infectious Diseases, University of Naples Federico II, Italy

\begin{abstract}
Hepatitis $C$ virus infection and diabetes mellitus are two major public health problems worldwide and the burden of these diseases is expected to increase in the near future. Hepatitis $\mathrm{C}$ virus is associated to autoimmune disorders of several organs (e.g. thyroid and kidney) and has recently been reported to be associated also to metabolic disorders including type 2 diabetes mellitus. Biologically, the homologies between the hepatitis $\mathrm{C}$ virus polyprotein and the pancreas antigens could underlie a mechanism of molecular mimicry that could lead to autoimmune diabetes (type 1 diabetes mellitus and latent autoimmune diabetes of adults). Here we review the data on the potential relationship between HCV-related chronic liver disease and autoimmune mediated diabetes mellitus.
\end{abstract}

Keywords: Hepatitis C virus; Autoimmune diabetes mellitus; Type 1 diabetes mellitus; Latent autoimmune diabetes of adults

Abbreviations: ICA: Islet Cells; IAA: Insulin; GADA: Glutamic Acid Decarboxylase; IA-2: Tyrosine Phospatase; ZnT8: Zinc Transporter 8

\section{Introduction}

Hepatitis C Virus (HCV) infection is the major cause of chronic liver diseases in western countries. It leads to liver cirrhosis, end-stage liver dysfunction and hepatocellular carcinoma. In addition HCV-related liver cirrhosis is the major cause of liver transplantation. According to the World Health Organization about 150-200 million people worldwide are HCV-infected. Almost 4 million and 1.5 million people in the USA and Italy, respectively, are chronic carriers of HCV and the prevalence reaches a peak in older subjects $[1,2]$. Also the prevalence of diabetes mellitus is alarming. In fact, in 2008 almost 177 million people were estimated to be affected by diabetes worldwide, and this number is expected to double in 2030, and to increase in young people especially in developing-countries [3]. The World Health Organization estimate published in 2013 is already more pessimistic. In fact, today more than 300 million people are estimated to be affected [1].

Whereas the association between HCV and autoimmune disorders (namely thyroid disorders, mixed cryoglobulinemia, monoclonal gammapathy, anti-LKM1-positive chronic hepatitis) is well-established, the association between HCV-related hepatitis and glucose metabolic disorders is still debated.

Here we review current knowledge about the potential relationship between HCV-related chronic liver disease and autoimmune-mediated diabetes mellitus.

\section{First Question: When can we Diagnose a Glucose Disorder as Autoimmune Diabetes Mellitus?}

The term "diabetes" refers to a cluster of pathologic chronic conditions that share the same clinical manifestation, namely impaired fasting glucose. This clinical feature is related to an impairment of insulin metabolism, either due to lack of insulin secretion or to peripheral insulin resistance or both [4]. According to the American Diabetes Association guidelines [4], diabetes is diagnosed when at least one of the following criteria is fulfilled:

- Typical symptoms of hyperglycemia or of a hyperglycemic crisis associated with a random plasma glucose $\geq 200 \mathrm{mg} / \mathrm{dl}$.
- Fasting plasma glucose $\geq 126 \mathrm{mg} / \mathrm{dl}$.

- Plasma glucose $\geq 200 \mathrm{mg} / \mathrm{dl}$ 2-hour after oral glucose load.

- A1C (glycated hemoglobin) $\geq 6.5 \%$ (48 mmol/mol).

Impaired fasting glucose is defined by a fasting glucose concentration between 100 and $125 \mathrm{mg} / \mathrm{dl}$, whereas impaired glucose tolerance is defined by a plasma glucose level between 140 and $199 \mathrm{mg} /$ $\mathrm{dl} 2$ hours after oral glucose load; both conditions are associated with an increased risk of developing overt diabetes mellitus.

The American Diabetes Association classification, which is based on etiopathogenetic criteria [4] defines three main types of diabetes (Table 1): type 1 diabetes mellitus (T1DM), type 2 diabetes mellitus (T2DM), and other types of diabetes besides the gestational form. Besides the classic risk factors (i.e. familiarity, type of diet, sedentary habits), also rubeola virus and coxsackie virus are associated with the onset of diabetes [5]. Moreover, the occurrence of cases of diabetes mellitus in subjects affected by HCV-related chronic hepatitis suggested that HCV may play a pathogenetic role in the development of the noninsulin-dependent immune-mediated forms of diabetes mellitus.

\section{Type 1 Diabetes Mellitus}

Diabetes mellitus type 1 , formerly known as insulin-dependent diabetes or juvenile diabetes, is characterized by immune-mediated destruction of pancreatic $\beta$-cells consequent with interactions between genetic susceptibility and environmental factors. Genetic susceptibility is associated with the HLA (Human Leukocyte Antigen) DQ region that accounts for about $40 \%$ of genetic risk [3]. The haplotypes most

*Corresponding author: Grazia Tosone, MD, Department of Clinical Medicine and Surgery - Section of Infectious Diseases, University of Naples Federico II, Via Sergio Pansini 5, 80131 Naples, Italy, Tel: ++39 0817463082; Fax: ++38 0817463094; E-mail: grazia.tosone@unina.it

Received August 24, 2013; Accepted October 18, 2013; Published October 23 2013

Citation: Tosone G, Maraolo AE, Palmiero G, Mascolo S, Orlando R (2013) Diabetes Mellitus Type 1, Latent Autoimmune Diabetes of Adults and Hepatitis C Virus: What we Know and what we Need to Know. J Diabetes Metab 4: 303 doi:10.4172/2155-6156.1000301

Copyright: (C) 2013 Tosone G, et al. This is an open-access article distributed under the terms of the Creative Commons Attribution License, which permits unrestricted use, distribution, and reproduction in any medium, provided the original author and source are credited. 
Citation: Tosone G, Maraolo AE, Palmiero G, Mascolo S, Orlando R (2013) Diabetes Mellitus Type 1, Latent Autoimmune Diabetes of Adults and Hepatitis C Virus: What we Know and what we Need to Know. J Diabetes Metab 4: 301. doi:10.4172/2155-6156.1000301

Page 2 of 5

$\sqrt{ }$ Type 1 Diabetes (due to $\beta$-cell destruction, leading to complete absence of insulin), classifiable in:

i. Immune-mediated

ii. Idiopathic

$\checkmark$ Type 2 Diabetes (due to a double mechanism such as insulin deficiency plus insulin-resistance)

$\checkmark$ Other specific types

i. Genetic defects of $\beta$-cell function

ii. Genetic defects in insulin action

iii. Diseases of exocrine pancreas

iv. Endocrinopathies

v. Drug or chemical induced forms

vi. Infections

vii. Uncommon forms of immune-mediated diabetes

vii. Other genetic syndromes sometimes associates with diabetes

$\checkmark$ Gestational diabetes mellitus

Table 1: Classification of Diabetes Mellitus - Adapted from the American Diabetes Association 2013 Position Statement.

often involved in this phenomenon are DQA1-0301, DQB1-0302 and DQB1-0201 [3]. In susceptible individuals, exposure to environmental factors, including viral infections, can activate the immune system and cause the autoimmune-mediated destruction of the pancreatic cells that govern insulin secretion [6-8]. In addition to the above- mentioned viral agents also echovirus and cytomegalovirus may trigger the autoimmune destructions of pancreatic beta cells [9-11].

The patient becomes symptomatic only when about $80 \%$ of $\beta$ cells are destroyed. Most patients affected by T1DM tested positive to antibodies against islet cells (ICA), insulin (IAA), glutamic acid decarboxylase (GADA), tyrosine phospatase (IA-2) and zinc transporter 8 (ZnT8) at the time of diagnosis. The diagnostic specificity of GADA, IAA, IA-2 and ZnT8 is 99\%; GADA has the highest diagnostic sensitivity, namely $70-90 \%$ [9]. Besides their diagnostic value, pancreatic autoantibodies could help to identify people with an increased risk for developing the disease, particularly the first-degree relatives of diabetic patients [10].

Type 1 diabetes mellitus commonly affects young people, being one of the most common pediatric endocrinopathies [11]. It has a peculiar geographic distribution: its incidence is higher in north European countries (e. g. 35.3/100,000 inhabitants in Finland) than in Asia (1/100,000 inhabitants), whereas it is intermediate in the USA (8/100,000 inhabitants) [9]. In a Mediterranean country such as Italy, the reported prevalence ranges between $0.4 \%$ and $1 \%$ of the general population [12-15].

\section{Latent Autoimmune Diabetes of Adults}

Latent Autoimmune Diabetes of Adults (LADA) is a form of adult autoimmune-mediated diabetes that phenotypically and genetically is intermediate between T1DM and T2DM [16,17]. Its diagnostic criteria are still controversial. The most widely accepted criteria, according to the Immunology of Diabetes Society (2004) [17] are: age over 30 years, presence of one or more diagnostic circulating autoantibodies and lack of requirement for insulin at least 6 month after diagnosis. Like patients with T1DM, subjects affected by LADA undergo destruction of $\beta$-cells. However, the onset age is higher and the progression of damage slower respect to T1DM, so that treatment with insulin might be delayed.

Latent autoimmune diabetes in adults occurs in individuals over 30-35 years of age and its clinical features are similar to those of T2DM, except LADA patients do not usually show classic predisposing risk factors such as obesity [18]. Detection of immunological markers is crucial for diagnosis: the autoantibodies are the same as those found in patients with T1DM, i.e. ICA, GADA, IAA, IA-2, anti-ZnT8. GADA appear earlier and persist longer than the other autoantibodies, and consequently it is possible to make a retrospective diagnosis [17]. The titer of GADA fluctuates over time and is no longer detectable 12 years after diagnosis [19]. Thus, several cases of "old" LADA forms are misdiagnosed as T2DM forms because of the disappearance of circulating antibodies. Thus, it has been assumed that LADA represents about $10-15 \%$ of all cases of non-insulin-dependent diabetes.

Based on GADA antibody titer, two forms of LADA have been defined [20]: type 1 LADA, which is characterized by high titers of GADA and displays genetic and phenotypic features similar to those observed in patients affected by T1DM; and type 2 LADA, which is characterized by low titers of GADA and displays phenotypic features similar to those observed in patients affected by T2DM with metabolic syndrome [17,21].

Since the detection of autoimmune antibodies can be expensive for some countries, a diagnostic algorithm has been devised in individuals who do not have risk factors for T2DM, detecting the plasma C-peptide and insulin levels and subsequently detecting GADA titer only in patients with reduced levels of C-peptide and insulin [18].

\section{Second Question: How can we Differentiate Type 1 Diabetes Mellitus and Latent Autoimmune Diabetes from Type 2 Diabetes Mellitus?}

Type 2 diabetes mellitus is the most common form of diabetes throughout the world. Its prevalence is about 2.7-3\% [22]. It results from the interaction between genetic factors which are not yet well known and environmental risk factors such as obesity and sedentary habits [23]. It mainly affects subjects over 40 years of age, although an increase of the disease has recently been observed in young people, children included [24].

Four metabolic abnormalities characterize T2DM [3]:

$\begin{array}{ll}\sqrt{ } & \text { Insulin resistance; } \\ \sqrt{ } & \text { Impaired insulin secretion; } \\ \sqrt{ } & \text { Obesity; } \\ \sqrt{ } & \text { An increase in endogen glucose production. }\end{array}$


Citation: Tosone G, Maraolo AE, Palmiero G, Mascolo S, Orlando R (2013) Diabetes Mellitus Type 1, Latent Autoimmune Diabetes of Adults and Hepatitis C Virus: What we Know and what we Need to Know. J Diabetes Metab 4: 301. doi:10.4172/2155-6156.1000301

The exact temporal sequence of these alterations remains to be established. However, it is probable that the increase in the number and function of fat cells plays an important role in reducing the sensitivity of peripheral tissues to insulin, thereby provoking hyperglycemia and compensatory hyperinsulinemia [25]. As a consequence of liver gluconeogenesis, glucose production worsens hyperglycemia by causing the release of free fatty acids into the bloodstream. Free fatty acids reach the liver thereby resulting in an accumulation of hepatic triglycerides, which in turn causes steatosis and, possibly, alteration of liver function, as well as an increase of circulating levels of atheromatous very low density lipoproteins. When the compensatory ability of $\beta$-cell fails and insulin levels can no longer maintain glucidic homeostasis, the classic diabetes symptomatology occurs (polyuria, polyphagia, polydipsia, up to hyperosmolar coma).

Recently, research has focused on the metabolic syndrome [26], defined as a cluster of strictly correlated clinical features, in which insulin resistance is the common pathogenetic determinant. The risk of developing T2DM and cardiovascular disease is very high. The "central axis" of adiposity, expressed as waist circumference, together with visceral fat and hepatic fat (non-alcoholic fatty liver disease and non-alcoholic steatohepatitis, is the most common feature associated with insulin resistance and metabolic syndrome. Since the metabolic syndrome has reached pandemic proportions (e.g. in the USA the ageadjusted prevalence is estimated at about $23 \%$ ), it will probably become a major cause of morbidity and mortality in the near future.

While T1DM can be easily distinguished from T2DM, it can be more difficult to differentiate Type 2 LADA from T2DM since many patients have very low or absent titer of serum autoimmune antibodies.

\section{Third Question: Is there a Link between Type 1 Diabetes Mellitus, Latent Autoimmune Diabetes and HCV Infection?}

Since the first report published in 1994, many epidemiological studies have confirmed the association between HCV infection and T2DM [27-46]. The prevalence of T2DM is higher (ranging from 20 to $50 \%)$ in HCV-infected patients than in patients with not HCV-related chronic liver disease or in the general population. Moreover, in the setting of $\mathrm{HCV}$-infected patients, the prevalence of diabetes mellitus seems to be significantly higher in the patients with advanced liver disease (cirrhosis) than in patients with chronic hepatitis (without cirrhosis) [46]. The problem is not negligible; in fact, it has been estimated that about 47 million people worldwide $(750,000$ people in the USA) may have diabetes mellitus associated with HCV infection [47]. Insulin resistance has been implicated in the association between HCV and T2DM [48]. The pathogenetic mechanisms of insulin resistance in HCV-positive patients are probably multiple and are based on a triangular interaction between steatosis or fatty liver disease (detected in about $50 \%$ of HCV-positive patients, particularly if infected by genotype 1 or 3 ), chronic inflammatory state of liver (mediated by the activation of macropahges and/or other immune cells plus increased production of pro-inflammatory cytochines) and lastly the inhibition of the insulin signaling pathway [48]. In contrast, little is known about the possible relationship between HCV infection and autoimmune diabetes (T1DM or LADA). Only two studies reported that acute or chronic HCV infection can be associated with the development of T1DM in patients without risk factors for diabetes [49,50], whereas the onset of T1DM has been reported in patients with chronic $C$ hepatitis only after starting antiviral treatment with interferon (plus ribavirin) [51].

The association between HCV infection and autoimmune diabetes seems to be biologically plausible. In fact, T1DM is thought to result from an interaction between host genetic susceptibility and environmental factors, viruses included. Since HCV is found in pancreatic beta-cells and leads to a reduction of glucose-stimulated insulin release [52], it is feasible that HCV initiates the process that leads to the destruction of pancreatic cells. Accordingly, homologies have been found between an HCV polyprotein and the pancreas antigens GAD65 and IA2. These homologies could drive a mechanism of molecular mimicry; the immune system would attack hepatic cells infected by the virus and also the pancreatic cells that present the homologous self antigen [53]. This hypothesis is not in line with the few epidemiological studies reported so far. In the setting of $\mathrm{HCV}$-infected patients the incidence of T1DM seems to be lower than the incidence of T2DM [48] and the prevalence of autoimmune pancreatic markers (GADA, ICA and IAA) does not seem to differ significantly from that of the general population $[50,54-$ 56]. The prevalence of pancreas-associated autoantibodies (including GADA) in HCV-infected patients, which at baseline (before antiviral treatment) is about $3 \%$, increased to $7 \%$ only during or after interferon therapy [55]. Only one study reported a significantly increased prevalence of IAA, albeit at a low titer, in HCV-infected patients before antiviral therapy ( $42 \%$ of the sample) versus control subjects $(2 \%)$. These titers did not change during antiviral therapy and no patient developed diabetes [56]. The authors postulated that HCV can trigger the production of IAA by polyclonal immunocyte activation without inducing an autoimmune attack in the pancreas; only antiviral therapy with interferon could amplify the pancreatic autoimmune aggression in these patients [56]. Increased production of autoantibodies against $\beta$-cells (i.e. GADA, IA2), which are considered a hallmark of LADA, in patients with HCV-related chronic hepatitis/cirrhosis could be hypothesized, but has not been confirmed [57]

Given that many cases of LADA could be missed after autoantibody disappearance, we wonder how many HCV-infected patients with an "old" history of T2DM are affected by LADA. Prospective, but unfortunately expensive, studies could clarify this question. In a preliminary study (unpublished data) of $51 \mathrm{HCV}$-infected patients (42 of them with chronic hepatitis and 9 with cirrhosis) routinely screened for pancreatic autoimmunity, we found that the rate of subjects tested positive to pancreatic autoantibodies (namely GADA, ICA and IA2) was higher (23.52\%) than previously reported in literature [57], independent of antiviral therapy.

\section{Conclusion}

In conclusion, we know a lot about HCV and metabolic disorders including T2DM, but the link between HCV and autoimmune diabetes remains obscure.

\section{Acknowledgements}

We thank Jean Ann Gilder (Scientific Communication srl., Naples, Italy) for substantive editing of the text.

\section{References}

1. http://www.who.int/mediacentre/factsheets/fs312/en/index.html

2. Armstrong GL, Wasley A, Simard EP, McQuillan GM, Kuhnert WL, et al. (2006) The prevalence of hepatitis $C$ virus infection in the United States, 1999 through 2002. Ann Intern Med 144: 705-714.

3. Kasper DL, Braunwald E, Hauser S, Longo D, Jameson JL, et al. (2008) Harrison Principles of Internal Medicine (17thedn) McGraw-Hill Professional.

4. American Diabetes Association (2013) Diagnosis and classification of diabetes mellitus. Diabetes Care 36: S67-S74.

5. Hober D, Alidjinou EK (2013) Enteroviral pathogenesis of type 1 diabetes: queries and answers. Curr Opin Infect Dis 26: 263-269. 
Citation: Tosone G, Maraolo AE, Palmiero G, Mascolo S, Orlando R (2013) Diabetes Mellitus Type 1, Latent Autoimmune Diabetes of Adults and Hepatitis C Virus: What we Know and what we Need to Know. J Diabetes Metab 4: 301. doi:10.4172/2155-6156.1000301

6. Lernmark A (1999) Type 1 diabetes. Clin Chem 45: 1331-1338.

7. Atkinson MA, Maclaren NK (1994) The pathogenesis of insulin-dependent diabetes mellitus. N Engl J Med 331: 1428-1436.

8. Wolf E, Spencer KM, Cudworth AG (1983) The genetic susceptibility to type 1 (insulin-dependent) diabetes: analysis of the HLA-DR association. Diabetologia 24: $224-230$.

9. Jenson AB, Rosenberg HS, Notkins AL (1980) Pancreatic islet-cell damage in children with fatal viral infections. Lancet 2: 354-358.

10. Pak CY, Eun HM, McArthur RG, Yoon JW (1988) Association of cytomegalovirus infection with autoimmune type 1 diabetes. Lancet 2: 1-4.

11. King ML, Shaikh A, Bidwell D, Voller A, Banatvala JE (1983) Coxsackie-B-virusspecific IgM responses in children with insulin-dependent (juvenile-onset; type I) diabetes mellitus. Lancet 1: 1397-1399.

12. McPhee SJ, Papadakis MA, Rabow MW (2012) Current Medical Diagnosis and Treatment. (55th edn), McGraw-Hill Professional Lange Medical Book.

13. Atkinson MA, Eisenbarth GS, Michels AW (2013) Type 1 diabetes. Lancet

14. Careddu P, Castello M, Giuffrè L, Principi N, Rubino A, et al. (2002) Pediatria generale e specialistica. Casa editrice Ambrosiana.

15. Karvonen M, Tuomilehto J, Libman I, LaPorte R (1993) A review of the recent epidemiological data on the worldwide incidence of type 1 (insulin-dependent) diabetes mellitus. World Health Organization DIAMOND Project Group. Diabetologia 36: 883-892

16. Seissler J (2008) Latent (slowly progressing) autoimmune diabetes in adults. Curr Diab Rep 8: 94-100.

17. Liao Y, Xiang Y, Zhou Z (2012) Diagnostic criteria of latent autoimmune diabetes in adults (LADA): a review and reflection. Front Med 6: 243-247.

18. Zimmet PZ (1999) Diabetes epidemiology as a tool to trigger diabetes research and care. Diabetologia 42: 499-518.

19. Desai M, Cull CA, Horton VA, Christie MR, Bonifacio E, et al. (2007) GAD autoantibodies and epitope reactivities persist after diagnosis in latent autoimmune diabetes in adults but do not predict disease progression: UKPDS 77. Diabetologia 50: 2052-2060

20. Li X, Yang L, Zhou Z, Huang G, Yan X (2003) Glutamic acid decarboxylase 65 autoantibody levels discriminate two subtypes of latent autoimmune diabetes in adults. Chin Med J (Engl) 116: 1728-1732.

21. Andersen MK, Lundgren V, Turunen JA, Forsblom C, Isomaa B, et al. (2010) Latent autoimmune diabetes in adults differs genetically from classical type 1 diabetes diagnosed after the age of 35 years. Diabetes Care 33: 2062-2064.

22. http://www.epicentro.iss.it/igea/PrimoPiano/usa_prevalenza.asp

23. Tuomilehto J, Lindström J, Eriksson JG, Valle TT, Hämäläinen H, et al. (2001) Prevention of type 2 diabetes mellitus by changes in lifestyle among subjects with impaired glucose tolerance. N Engl J Med 344: 1343-1350.

24. Goran MI, Ball GD, Cruz ML (2003) Obesity and risk of type 2 diabetes and cardiovascular disease in children and adolescents. J Clin Endocrinol Metab 88: $1417-1427$

25. Weyer C, Funahashi T, Tanaka S, Hotta K, Matsuzawa Y, et al. (2001) Hypoadiponectinemia in obesity and type 2 diabetes: close association with insulin resistance and hyperinsulinemia. J Clin Endocrinol Metab 86: 1930-1935.

26. Bugianesi E, Salamone F, Negro F (2012) The interaction of metabolic factors with HCV infection: does it matter? J Hepatol 56 Suppl 1: S56-65.

27. Mason AL, Lau JY, Hoang N, Qian K, Alexander GJ, et al. (1999) Association of diabetes mellitus and chronic hepatitis $C$ virus infection. Hepatology 29: 328-333.

28. Romero-Gómez M, Fernández-Rodríguez CM, Andrade RJ, Diago M, Alonso S et al. (2008) Effect of sustained virological response to treatment on the incidence of abnormal glucose values in chronic hepatitis C. J Hepatol 48: 721-727.

29. Dumoulin FL, Leifeld L, Sauerbruch T, Spengler U (1999) Autoimmunity induced by interferon-alpha therapy for chronic viral hepatitis. Biomed Pharmacother 53: $242-254$.

30. Garrido Serrano A, Guerrero Igea FJ, Lepe Jiménez JA, Palomo Gil S, Grilo Reina A (2001) [Hyperinsulinemia in cirrhotic patients infected with hepatitis C virus]. Gastroenterol Hepatol 24: 127-131.

31. Lecube A, Hernández C, Genescà J, Esteban JI, Jardí R, et al. (2004) High prevalence of glucose abnormalities in patients with hepatitis $C$ virus infection: a multivariate analysis considering the liver injury. Diabetes Care 27: 1171-1175.

32. Lecube A, Hernández C, Genescà J, Simó R (2006) Glucose abnormalities in patients with hepatitis $\mathrm{C}$ virus infection: Epidemiology and pathogenesis. Diabetes Care 29: 1140-1149.

33. Ryu JK, Lee SB, Hong SJ, Lee S (2001) Association of chronic hepatitis C virus infection and diabetes mellitus in Korean patients. Korean $\mathrm{J}$ Intern Med 16: 18-23.

34. Thuluvath PJ, John PR (2003) Association between hepatitis C, diabetes mellitus, and race. a case-control study. Am J Gastroenterol 98: 438-441.

35. Zein NN, Abdulkarim AS, Wiesner RH, Egan KS, Persing DH (2000) Prevalence of diabetes mellitus in patients with end-stage liver cirrhosis due to hepatitis C alcohol, or cholestatic disease. J Hepatol 32: 209-217.

36. Bigam DL, Pennington JJ, Carpentier A, Wanless IR, Hemming AW, et al. (2000) Hepatitis C-related cirrhosis: a predictor of diabetes after liver transplantation. Hepatology 32: 87-90.

37. Caronia S, Taylor K, Pagliaro L, Carr C, Palazzo U, et al. (1999) Further evidence for an association between non-insulin-dependent diabetes mellitus and chronic hepatitis C virus infection. Hepatology 30: 1059-1063.

38. Allison ME, Wreghitt T, Palmer CR, Alexander GJ (1994) Evidence for a link between hepatitis $C$ virus infection and diabetes mellitus in a cirrhotic population. J Hepatol 21: 1135-1139.

39. Del Campo JA, Romero-Gómez M (2009) Steatosis and insulin resistance in hepatitis C: a way out for the virus? World J Gastroenterol 15: 5014-5019.

40. del Olmo JA, Serra MA, Rodrigo JM (1996) Liver cirrhosis and diabetes mellitus. J Hepatol 24: 645

41. di Cesare E, Previti M, Russo F, Brancatelli S, Ingemi MC et al. (1996) Interferon-alpha therapy may induce insulin autoantibody development in patients with chronic viral hepatitis. Dig Dis Sci 41: 1672-1677.

42. Guerreo Igea FJ, Garrido Serrano A, Lepe Jiménez JA, Palomo Gil S (1998) [High prevalence of diabetes mellitus in patients with chronic hepatitis $C$ virus infection]. Med Clin (Barc) 111: 676-677.

43. Hadziyannis S, Karamanos B (1999) Diabetes mellitus and chronic hepatitis C virus infection. Hepatology 29: 604-605

44. Huang JF, Dai CY, Hwang SJ, Ho CK, Hsiao PJ, et al. (2007) Hepatitis C viremia increases the association with type 2 diabetes mellitus in a hepatitis $\mathrm{B}$ and $\mathrm{C}$ endemic area: an epidemiological link with virological implication. Am J Gastroenterol 102: 1237-1243.

45. Knobler H, Schihmanter R, Zifroni A, Fenakel G, Schattner A (2000) Increased risk of type 2 diabetes in noncirrhotic patients with chronic hepatitis $C$ virus infection. Mayo Clin Proc 75: 355-359.

46. Ozyilkan E, Arslan M (1996) Increased prevalence of diabetes mellitus in patients with chronic hepatitis C virus infection. Am J Gastroenterol 91: 1480-1481.

47. Wlazlo N, Beijers HJ, Schoon EJ, Sauerwein HP, Stehouwer CD, et al. (2010) High prevalence of diabetes mellitus in patients with liver cirrhosis. Diabet Med 27: 1308-1311.

48. Serfaty L, Capeau J (2009) Hepatitis C, insulin resistance and diabetes: clinica and pathogenic data. Liver Int 29 Suppl 2: 13-25.

49. Chen LK, Chou YC, Tsai ST, Hwang SJ, Lee SD (2005) Hepatitis C virus infection-related Type 1 diabetes mellitus. Diabet Med 22: 340-343.

50. Fabris P, Floreani A, Tositti G, Vergani D, De Lalla F, et al. (2003) Type 1 diabetes mellitus in patients with chronic hepatitis $\mathrm{C}$ before and after interferon therapy. Aliment Pharmacol Ther 18: 549-558.

51. Oka R, Hiroi N, Shigemitsu R, Sue M, Oshima Y, et al. (2011) Type 1 Diabetes Mellitus Associated with Pegylated Interferon-Ît Plus Ribavirin Treatment for Chronic Hepatitis C: Case Report and Literature Review. Clin Med Insights Endocrinol Diabetes 4: 39-45

52. Masini M, Campani D, Boggi U, Menicagli M, Funel N, et al. (2005) Hepatitis $\mathrm{C}$ virus infection and human pancreatic beta-cell dysfunction. Diabetes Care 28: $940-941$.

53. Bogdanos DP, Rigopoulou El (2007) Viral/self-mimicry and immunologica cross-reactivity as a trigger of hepatic $\mathrm{C}$ virus associated autoimmune diabetes. Diabetes Res Clin Pract 77: 155-156. 
Citation: Tosone G, Maraolo AE, Palmiero G, Mascolo S, Orlando R (2013) Diabetes Mellitus Type 1, Latent Autoimmune Diabetes of Adults and Hepatitis C Virus: What we Know and what we Need to Know. J Diabetes Metab 4: 301. doi:10.4172/2155-6156.1000301

Page 5 of 5

54. Piquer S, Hernández C, Enriquez J, Ross A, Esteban JI, et al. (2001) Islet cell and thyroid antibody prevalence in patients with hepatitis $C$ virus infection: effect of treatment with interferon. J Lab Clin Med 137: 38-42.

55. Betterle C, Fabris P, Zanchetta R, Pedini B, Tositti G, et al. (2000) Autoimmunity against pancreatic islets and other tissues before and after interferon-alpha therapy in patients with hepatitis C virus chronic infection. Diabetes Care 23: $1177-1181$.
56. Fabris P, Betterle C, Greggio NA, Zanchetta R, Bosi E, et al. (1998) Insulindependent diabetes mellitus during alpha-interferon therapy for chronic vira hepatitis. J Hepatol 28: 514-517.

57. Hiéronimus S, Fredenrich A, Tran A, Benzaken S, Fénichel P (1997) Antibodies to GAD in chronic hepatitis C patients. Diabetes Care 20: 1044
This article was originally published in a special issue, Diabetes: Case Studies handled by Editor(s). Dr. Vishwamitra Sharma, Nottingham University Hospital,

UK 